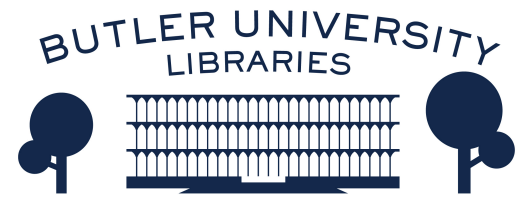

Journal of Hindu-Christian Studies

Volume 31 Celebrating Rāmānuja at 1000: The

Heritage and Promise of the Study of Rāmānuja

in a Christian-Hindu Comparative Theology

Article 18

2018

\title{
Thinking the Creator and Creature Together': How Rāmānuja's Account of Scriptural Meaning Encourages Unitive Language in Christian Discourse about God and the World
}

Martin Ganeri OP

Blackfriars Hall, University of Oxford

Follow this and additional works at: https://digitalcommons.butler.edu/jhcs

\section{Recommended Citation}

OP, Martin Ganeri (2018) "Thinking the Creator and Creature Together': How Rāmānuja's Account of Scriptural Meaning Encourages Unitive Language in Christian Discourse about God and the World," Journal of Hindu-Christian Studies: Vol. 31, Article 18.

Available at: https://doi.org/10.7825/2164-6279.1695

The Journal of Hindu-Christian Studies is a publication of the Society for Hindu-Christian Studies. The digital version is made available by Digital Commons @ Butler University. For questions about the Journal or the Society, please contact cbauman@butler.edu. For more information about Digital Commons @ Butler University, please contact digitalscholarship@butler.edu. 


\title{
'Thinking the Creator and Creature Together': How Rāmānuja's Account of Scriptural Meaning Encourages Unitive Language in Christian Discourse about God and the World
}

\author{
Martin Ganeri OP \\ Blackfriars Hall, University of Oxford
}

\begin{abstract}
The interest shown by Christian theologians in the work of Rāmānuja has tended to focus on his doctrinal account of God and his embodiment cosmology. This paper explores instead Rāmānuja's account of language in general and then those Vedāntic texts that grammatically identify the world with the ultimate reality, Brahman. It shows how Rāmānuja is able to affirm the primary meaning of these texts, but in such a way as to express the complete contingency of the world on the ultimate reality as well as their distinction. The paper goes on to develop a theological dialogue between Rāmānuja and the Christian Scholastic theology of Thomas Aquinas. Whereas Christian theology has tended generally to avoid language that identifies the world with God as being pantheistic and opposed to the doctrine of creation, an appropriation of Rāmānuja's account of language encourages the use of such unitive language as a powerful way of expressing the unique relation that is creation.
\end{abstract}

\section{Introduction}

At the heart of Rāmānuja's theology is his exegesis of the Vedāntic scriptural texts. In support of his exegesis Rāmānuja advances a number of arguments about how language works both in general and in the theological context. And he puts forward a distinctive account of the semantic relation between language and the reality of entities in the world, including the nature of their relationship with the ultimate reality, Brahman. A central application of this is in his account of those scriptural texts that grammatically identify the world with Brahman. For Rāmānuja such statements can be taken at their primary meaning without denying that the world is distinct from Brahman and that it exists as a reality wholly dependent on Brahman, as the body of Brahman. It is his account of language that enables him to resolve the apparent contradiction that this involves. For such identity statements, taken straightforwardly,

\footnotetext{
Fr. Martin Ganeri OP is Prior Provincial of the English Province of the Order of Preachers (Dominican Order). He has an MA in Classics and Oriental Studies, an MPhil in Ancient Indian Archaeology at Cambridge, and a DPhil in Theology at Oxford. At Blackfriars Hall, University of Oxford, he teaches courses in Sacred Scripture, Phenomenology and Theology of Religions, and Archaeology. His recent book, Hindu Thought and Western Theism: The Vedanta of Ramanuja (2015), was published by Routledge.
} 
imply that Brahman and the world form a substantial unity, i.e. that they have a metaphysical identity. Yet, Rāmānuja's cosmological account denies such a substantial unity.

Christian theological engagement with Rāmānuja has tended to give more attention to his cosmology as a resource for the creative enrichment of Christian theology. ${ }^{2}$ However, his account of language is also very interesting and in this article I would like to argue that Christian theology might also embrace and appropriate his account of identity statements as a resource for expressing the unique relationship that is creation. ${ }^{3}$ Christian theology has generally shunned such identity statements on the basis that they do imply a pantheistic relationship, a substantial unity, one that is alien to Christian understanding of the relationship between God and the world. Engagement with Rāmānuja's account of language, however, encourages a creative rethinking of Christian accounts of language when it comes to this relationship.

\section{Rāmānuja: language and reality}

The presence of sentences in which the world is grammatically identified with Brahman is a striking feature of the Vedāntic scriptures and the question of how to interpret them becomes a major topic in the Vedāntic schools. Of particular concern are those that identify the finite self with Brahman, such as 'I am Brahman' (ahaṃ brahmāsmi, Bṛhadāranyaka Upanișad 1.4.10) or 'That you are, Śvetaketu' (tat tvam asi śvetaketu, Chāndogya Upaniṣad 6.8.7ff). For the Advaitic school these are taken as affirming a strict identity between the finite self and Brahman and this then forms the central doctrine within Advaita as a whole. For those Vedāntic schools, such as Rāmānuja's, that affirm that the world and the finite selves within human beings are distinct from Brahman there is inevitably the question of what meaning to give them, when their primary seem to contradict the distinction being otherwise maintained. Rāmānuja's general account of language emerges in contexts where he is discussing these texts and serves to give a basis for being able to justify his exegesis of them.

Rāmānuja's first develops a general account of how to understand sentences where words of the same case are co-ordinated with each other, such as 'The cloth is red,' or 'Devadatta is dark-complexioned, young, reddish-eyed, not poor, not stupid, of irreproachable character.' (Rāmānuja Śrī Bhāṣya (Ś.Bh.) 1.1.13). ${ }^{4}$ For Rāmānuja it is commonly agreed that what characterises such sentences is that there is the "predication to one entity of several words having different reasons for their application.' (Ś.Bh1.1.13). ${ }^{5}$ There is a single grammatical subject about which a number of predicates are made and these predicates inform us in different ways about the nature of that subject. And in terms of their relation to reality, they refer to single entities in the world and tell us about what kind of entities they are and what they are otherwise like.

Supporting this account is Rāmānuja's argument that there is a structural correspondence between language and reality, taking the inflected language of Sanskrit as his model. In other words, the differentiation present within Sanskrit words constructed of verbal roots and their affixes, as well as that present in sentences composed of a number of words, reflects real differences in entities themselves. As he puts it:

Language, in particular, is capable only of denoting an entity having distinct attributes, because it takes the form of words and sentences. For a word is the union of a root and an affix. Because of the difference in the meaning of the root and 
affix, it cannot but make known a complex object. And the differentiation within a word is linked to differentiation in the object (Ś.Bh. 1.1.1). ${ }^{6}$

A second aspect of Rāmānuja's account of language is that he asserts that the reality of how entities are determines the meaning of language for us. In the case of the redness of a cloth we know that the redness only exists by virtue of the cloth. The redness inheres in the cloth. This Rāmānuja calls the relationship of a mode (prakāra). For Rāmānuja this means that part of the primary meaning of the word 'red' is the cloth, in that part of our understanding of what 'red' means is that it refers to the cloth in which it inheres. Thus, for Rāmānuja, a sentence like 'the cloth is red' has a double primary meaning; first, its primary meaning is that the cloth is characterised by the colour red and is one entity; second, the meaning is that 'red' is a mode of the cloth, referring us to the cloth.

Rāmānuja extends this account to include the relationship between a body and its self and to sentences that talk of bodies and their selves. The relation of a body to its self is a modal relationship, like that of an attribute and the entity in which it inheres, since the body also only exists as dependent on the self. So, any word for a body also refers us to the self within it. This is also part of the primary meaning of the word. Summing up both his account of the meaning of words denoting modes and how it relates to the relationship of bodies to the selves of which they are the bodies, Rāmānuja states:

Because a body is the mode of the self that possesses the body, and because words naming a mode terminate in the mode possessor, words naming a body rightly terminate in the self that possesses the body. For a mode is the part perceived as 'thus' in some entity perceived as 'this is such.' A word that makes the mode known has its terminus of meaning in the mode possessor, rightly doing so because the understanding of a mode depends on the mode possessor, since the mode depends for its existence on the mode possessor (Ś.Bh. 1.1.13)

Rāmānuja uses this account of language to support his exegesis of those Vedāntic scriptural texts that co-ordinate the world and Brahman, in particular the statement, 'That you are, Śvetaketu.' (Chāndogya Upaniṣad 6.8.7ff). For Rāmānuja the Vedānta texts make known to us that the world, or more precisely each entity within the world, is the body of Brahman, who is its inner self. This is something that is revealed to us, rather than something obvious to us from observation of the world. But once we do know this, then what the language we use for entities in the world means for us changes. Words for entities in the world now also refer us to Brahman as the self on which they depend for their existence, since we now know that they are modes of Brahman (Ś.Bh. 1.1.13 M. 57-60):

Persons untutored in the Vedānta do not see that Brahman is the self of all individuals and types of beings, and they think that the terminus expressed by all [substance] words is only the various types of being [overtly expressed by these words]. But these are in fact only a part of what is expressed. Once they study the Vedānta statements they know that everything is ensouled by Brahman and that all words express Brahman as conditioned by various modes, in that everything is Brahman's effect and he is their inner controller (Rāmānuja, Vedārtha Samgraha para. 21). ${ }^{8}$

The text, 'That you are, Śvetaketu,' cannot be taken to mean that the world itself is strictly identical with Brahman, since we know from 
revelation that each entity in the world is the body of Brahman, distinct from Brahman, having its own substantial existence, but completely dependent on Brahman for its existence. But, at the same time, the text can still be taken at its primary meaning, because, in the light of revelation, we now see the primary meaning of words for entities in the world refers us to Brahman. Thus, in the sentence, 'That you are, Śvetaketu, the word 'you,' as well as the word, 'That,' refer us to Brahman. The grammatical identity within the sentence can be upheld, since both words refer to Brahman. Hence, such statements express in a particularly emphatic way the relationship the world has with Brahman:

In the case of the co-ordinative text, 'That you are,' the word 'that' makes know the supreme Self who is the maker of the world, who is characterised by all auspicious qualities, whose will is always realised and from whom any suggestion of any taint is rejected and the word, 'you' makes known the supreme Self who has as his body the embodied finite self (Ś.Bh. 1.1.13). ${ }^{9}$

\section{Christian Discourse about God and the World}

Turning now to Christian theological engagement with Rāmānuja, I would like first to mention a comment made by the contemporary Christian theologian David Burrell C.S.C. Burrell became familiar with another form of Christian encounter with Vedānta, in the form of the work of twentieth century Catholic Thomist theologians, who brought the Scholastic thought of Thomas Aquinas into a sustained encounter with classical Advaita Vedānta. Two of these theologians, Richard de Smet S.J. and Sara Grant R.S.C.J. argued for a convergence between the account given of the Brahman and Brahman's relationship with finite reality found in Advaita Vedānta and the account of God and of God's relationship with the world found in the work of Thomas Aquinas, based on a realist reading of some works of Śamkara. In the light of becoming familiar with their work in the form of a set of lectures given by Sarah Grant, ${ }^{10}$ Burrell has commented in a number of his writings that Vedāntic non-dualistic language might help us, as he puts it, 'think creator and creature together. ${ }^{11}$

Burrell does so in the context of his own detailed examination of Christian Scholastic theology's use of Islamic thought as Christian Scholastics sought to find an adequate way of expressing the creational relation between God and the world. Both Islamic and Christian thinkers were faced by the inadequacy of the ordinary causal language describing types causation within the world for expressing the unique case of causation that is creation. Creation is the doctrine that the world is produced by God in such as way that the world is distinct from God, but dependent for the entirety of its existence on God at all times. The world is distinct from God, but does not exist separate from God. The world has a substantial existence of its own, but is totally dependent for this existence on God. On the one hand, the ordinary causal language of a human craftsman making other things can be used to express the production of the world by God, but suggests that world is separate from God, since the things made by craftsmen are separate from their maker. On the other hand, the causal language of natural generation or emanation of one entity from another thing does expresses the total dependence of the world on God at all times, but suggests that God and the world are one substance in a pantheistic fashion.

Christian scholastic theologians such as Thomas Aquinas sought to combine both types of causal language, interpreting them in such a way that the disadvantages of both were minimized (e.g. Aquinas, Summa Theologiae (S.T.) 1.44-45). For his part, Burrell suggests 
that we might find in Vedāntic language a further resource for expressing the creational relationship that helps us express this unique relation, one that complements existing solutions. Following his lead, I want to explore how Rāmānuja's own account of language and of Vedāntic identity statements can itself serve as a kind of catalyst for using identity language in a Christian context, without any fear that we will end up with a pantheistic account. Following the lead of those earlier Christian theologians who engaged with Advaita Vedānta I will also take Thomas Aquinas as the point of encounter on the Christian side and ask of his theology whether it can accommodate and be enriched by an engagement with Rāmānuja. Since the encounter with Advaita Vedānta was itself based on a realist reading of Advaita Vedānta, this can fittingly be extended to an encounter with the realist form of Vedānta found in Rāmānuja.

\section{Aquinas: language and reality}

For his account of language in general Aquinas draws on Aristotle and on Aristotle's semantic triangle of entities, words and concepts. Here words are said to refer to entities via the concepts of those entities formed in human minds. When we use a sentence like 'Socrates is a human being and is wise,' we have a concept in our minds about what a human being is and what wisdom is. The concept is the definition or ratio of what a human being and what wisdom are:

According to the Philosopher (Peri Herm. Lib. 1, 1.1, n.2) words are signs of ideas and ideas the likenesses of entities. And so it is evident that words signify entities through the medium of the concept the intellect has [of the entity]. It follows therefore that we can give a name to any entity insofar as we can understand it (S.T. 1.13.1). ${ }^{12}$
The ratio that a name signifies is the concept of the intellect about the things signified by the name (S.T. 1.13.4). ${ }^{13}$

So, for Aquinas, language relates to the reality of the world through the medium of human thought. This means that words and sentences are dependent on human agreement about what they mean and how they can be used (e.g. Aquinas, In Peri Hermeneias Lib. 1, 1.2, n.5).

We noted that Rāmānuja affirms a structural correspondence between language and the reality of entities. Likewise, for Aquinas there is a structural correspondence in the relation between language and finite entities, via the concepts formed about these entities. In a sentence like 'Socrates is a human being and is wise,' the ratio or defining concept of what 'human being' and 'wise' is a mental concept in the human being using this language. But the sentence, 'Socrates is a human being and is wise' is said to be a true sentence only if it corresponds to the reality of what Socrates is, since truth, for Aquinas, is the conformity of the mind and entities, as that is expressed in language (S.T. 16.2). Thus, the ratio of 'human being' and 'wise' is something that can also be said to inhere in the entity itself in the sense that it is the reality of what kind of entity a human being is and what kind of quality being wise is. The different concepts correspond to different aspects of the reality of finite entities. ${ }^{14}$

For Aquinas the exception to this is God, whose existence is entirely simple, that is to say, not characterized by the forms of composition that characterize finite reality. For Aquinas we can use certain words that denote perfections of existence, such as 'wise,' of both finite entities and of God and predicate them literally both of finite entities and of God. Yet in so doing we are speaking analogously, since how these words correspond to the 
reality of finite entities and God is different. In the case of a finite entity, such as Socrates, his being a human being and his being wise correspond to really different aspects of his existence, but in God there is only the infinite existence that is God and while to say that he is wise does correspond to the reality of his existence, this does not correspond to real differences in his existence (S.T. 1.13. 2,5).

We can already see here certain convergences between Aquinas' account of language and how it relates to reality and that of Rāmānuja. For Aquinas, when we use a sentence like, 'Socrates is a human being and is wise' we name aspects of what kind of entity Socrates is and what he is like and these are aspects that inhere in Socrates. Moreover, the human nature of Socrates and his being wise only exist because they are found in the concrete entity called Socrates. This is what Rāmānuja calls the modal relationship. So, it might also seem natural, after reading Rāmānuja, to extend Aquinas' account and also say that when we use these words they also refer us to the concrete entity we are talking about. Their primary meaning for us extends to that concrete entity on which they depend for having existence. Moreover, in terms of God and the world, for Aquinas we know in the light both of revelation and human reasoning that the world is created by God. We know that the world has been produced by God and depends on God for its existence at all times. So, we could say that for Aquinas the world has a modal relationship with God, in the wider scope of that term given by Rāmānuja.

Now, if we put these things together, I think we can see how Rāmānuja's account of identity statements between Brahman and the world can be appropriated creatively and usefully by a Christian theologian using Aquinas' account both of language and of creation. We noted that for Aquinas words refer to entities via concepts and that human agreement determines what words and sentences mean. In the theological context in which we know that the world is created our understanding of the reality of the world acquires a new depth. And we could agree that the concepts we have about things in the world should reflect this new depth. Hence, what the words themselves mean for us extends to the Creator on whom all the entities we name by these words depend. In this deeper theological context, a word like 'human being' would refer immediately to the concrete human being in which human nature inheres, but also to the God on whom the existence of any concrete human being depends. In effect, this is what Rāmānuja himself does. In the light of revelation he expands the concept of what the primary meaning of words for entities in the world is.

Thus, a sentence like 'Socrates is God' could be made by a Christian theologian, if it is said that the concept of what 'Socrates' includes the meaning that he is created by God. The sentence would mean that Socrates is a human being who depends for his existence on God. It would not mean that Socrates is the same as God, or has a substantial unity with God. We could think creature and creator together and do so in way that upholds both the distinct reality of the creature and the inseparable relation of dependency that are both elements of the doctrine of creation.

For Aquinas words denoting perfections of existence, such as 'wise,' can be predicated literally, if analogously, of finite entities and of God because the ratio or defining concept of such terms is not tied to any particular mode of existence. They can characterise both the finite and composite mode of existence found in finite entities and the infinite and simple mode of existence found in God. Yet with words like 'human being' the ratio or defining concept is tied to finite reality, to the nature of 
created things, since a 'human being' is inherently a finite and composite entity. The Bible often does predicate words that denote finite or created reality of God, but within Aquinas' understanding of this, such language is inherently metaphorical and expresses ways in which God is similar to created entities (S.T. 1.13. ad.1). For instance, when the Bible calls God a 'rock' (Psalm 18:2) or a 'shepherd' (Psalm 23: 1) it means that God is a secure refuge for human beings to rely on like a rock or is the guide, provider and protector of human beings, like a shepherd. Yet, what underlies both analogous and metaphorical language is the reality that God is the cause of all the aspects of existence found in finite entities. Finite entities such a human being only exist as such because God causes them to be and they can only be wise or good or powerful because God causes them to be such. Thus, a creative use by Christian theologians of identity statements to express the inseparable relationship of dependence between God and the finite entities that make up the created world helps make manifest something that is already present in Aquinas' wider discussion of how language is used of God.

This creative extension of Aquinas' account of language accords also with ways in which Aquinas himself interprets sentences in the Bible where human beings are said to share in the divine nature. In terms of creation there are few such texts, but they are not completely absent and have required christian exegetes to explain how they could be true. Thus in Psalm 82:6 it is said, 'I said, 'You are gods, sons of the Most High, all of you.' For Aquinas the meaning of this sentence cannot be an affirmation of any strict identity between human beings and God, but rather that human beings have a certain likeness to the divine nature. As he puts it:

This name, 'God' is nonetheless communicable [to other entities], not according to its whole signification, but according to some aspect of it through a certain likeness, so that they are called gods, who share in an aspect of divinity through a likeness, according to the text, 'I said, You are gods.' (Psalm 82.6) (S.T. 1.13.9). ${ }^{15}$

In other words, human beings share in aspects of the nature of God, above all by having intellect and will whereby they can be said to be made in the image of God.

In keeping with this, Aquinas explains the meaning of texts where human beings and God are identified in the order of salvation or of grace, sentences that have led to rich spiritual language of 'divinization' within the Christian tradition. Thus, in 2 Peter 1:4, the promise is given that by divine power human beings can 'become partakers of the divine nature' (R.S.V tanslation) or in John 17: 21, Christ prays 'that they be one even as thou, Father, art in me, and I in thee, that they also may be in us' (R.SV.) For Aquinas these texts do not mean that human beings enter into a substantial unity with God, but rather that there is a certain assimilation to the divine nature through participation in divine grace. It is this operation of divine grace that makes it possible to talk of the deification of human beings:

The gift of grace exceeds every faculty of created nature, since it is nothing other than a certain sharing in the divine nature, which exceeds every other nature.

For it is necessary that only God deifies by communicating a fellowship in the divine nature through a certain participated likeness (S.T. 1-2.112.1). ${ }^{16}$

In the first place, this is a metaphorical way of speaking, just as the predication of words that express concept that have an inherently finite or creaturely connotation of God are metaphorical, since the divine nature as such is inherently incompatible with finite reality. 
Yet, such language does denote the real assimilation of human beings to the divine nature, insofar as the life of human beings is drawn into a fellowship with the divine nature.

\section{Concluding Remarks}

Thus, a further use of identity statements to include the modal dependency advanced by Rāmānuja can creatively extend the account Aquinas already gives. It can provide Christian theologians working with the Thomist or similar theology a resource to 'think the creator and creature together.' One final comment can support such a creative appropriation of Rāmānuja's thought as a natural extension of what Aquinas himself does. Aquinas does have an account of how Christian theology can engage with nonChristian thought. ${ }^{17}$ For Aquinas, Christian theology can take from non-Christian thought

\section{Notes}

${ }^{1}$ For a discussion of this, see Ganeri, M (2015). Indian Thought and Western Theism: the Vedānta of Rāmānuja. London and New York: Routledge, chapter 4.

DOI:

https://doi.org/10.4324/9781315731339

${ }^{2}$ Lott, E. J. (1976) God and the Universe in the Vedāntic Theology of Rāmānuja. Madras: Rāmānuja Research Library; Carman, J.B. (1974) The Theology of Rāmānuja. New Haven, CT: Yale University Press.

${ }^{3}$ Rāmānuja's theory of language is given sustained treatment in Liner, J.J. (1986) The Face of Truth: A Study of Meaning and Metaphysics in the Vedāntic Theology of Rāmānuja. Albany: State University of New York Press. This article draws on his work and extends it into a comparative theological engagement with Christian thought. In Ganeri, M. (2015, I undertake a wider comparative study of Rāmānuja and Thomas Aquinas and this article is an extension of that comparative study into the particular aspect of way both thinkers give accounts of language in a theological context.

${ }^{4}$ The Sanskrit text used of the Śrī Bhāssyam is the Melkote critical edition Laksmithathachar, M.A. (chief ed.) Śrī Bhāsyam. Melkoțe: Academy of Sanskrit Research. Vols 1-4 (1985,1987,1990,1991). what he calls 'likenesses' (similitudines). A likeness is where something in the natural world or in human thought is taken to resemble something that revelation reveals to us. Christian theology can use such elements of non-Christian thought, be it about the nature of the world, the nature of language, causality and so on in order to make revelation more intelligible. In keeping with this, a Christian theologian could also take the likeness identified in Rāmānuja between ordinary language and language in the theological context as a model for expanding the way Christian theology uses language about creation.

Melkoțe Vol. II, pp. 45, 51: raktah pațo bhavati, devadettah śyāmo yuvā lohitākșaḥ adīnaḥ akrpaṇạ anavadyah

${ }^{5}$ Melkoṭe Vol. $\quad$ II,
śabdānām
ekasminnarthe vrttih

${ }^{6}$ Melkoțe Vol. I, p. 60: śadbasya tu viśeșena saviśeșa eva vastuni abhidhānasāmarthyam padavākyarūpeṇa pravrtteh. prakrtipratyayogena hi padatvam. akrtipratyayayoh arthabhedena padasyaiva viśiștārthapratipādanam avarjanīyam. padabhedaśca arthabhedanibandhanah.

${ }^{7}$ Melkoțe Vol. II, p.58: śarīrasya śarìrinam prati prakāratvāt prakāravācinām ca śabdānām prakāriṇyeva paryvasanāt śarīravācinām śabdānām śarīiparyavasānaṃ nyāyyam. prakāro hi nāma 'idam ityam' iti pratìyamāne vastuni 'ittham' iti pratīyamānaḥ aṃśạ. tasya tadvastvapekșatvena tatpratiteh tadapekșatvāt, tasminneva paryavasānam yuktamiti, tasya pratipādako pi śabda tasminneva paryavasyati

${ }^{8}$ Quoted from Lipner, J.J. (1986) The Face of Truth. p.42. DOI: https://doi.org/10.1007/978-1349-07915-5

9 Melkoțe Vol. II, p.60: 'tattvamasi' iti sāmānādhikaraṇye, 'tat' padaṃ jagatkaraṇabhūtaṃ 
satyasaṃkalpam sarvakalyāṇaguṇākaraṃ nirastasamastaheyagandham paramātmānam ācaște; 'tvam' iti ca tameva saśarīrajīvaśarīrakam ācaste

${ }^{10}$ The Teape lectures, which Sara Grant gave in Cambridge in 1989, were subsequently published as Grant, S. R.S.C.J. (2002). Toward an Alternative Theology: Confessions of a Non-Dual Christian. Notre Dame, Indiana: University of Notre Dame, with an introduction by Bradley J. Malkovsky

${ }^{11}$ Burrell, D. (2003) 'Aquinas's Appropriation of Liber de causis to Articulate the Creator as Cause-of being in F. Kerr (ed) Contemplating Aquinas; On the Varieties of Interpretation . London: SCM; (2004) 'Thomas Aquinas and Islam,' Modern Theology 20:71-89. DOI: https://doi.org/10.1111/j.14680025.2004.00243.x

${ }^{12}$ All Latin texts are taken from: Busa, R. SJ et al. (2000-12) Thomae de Aquino Super Boetium De Trinitate in Corpus Thomisticum: Index Thomisticus, Pamplona: Fundación Tomás de Aquino (Latin text. Web edition): secundum philosophum, voces sunt signa intellectuum, et intellectus sunt rerum similitudines. Et sic patet quod voces referuntur ad res significandas, mediante conceptione intellectus. Secundum igitur quod aliquid a nobis intellectu cognosci potest, sic a nobis potest nominari.
13 Ratio enim quam significat nomen est conceptio intellectus de re significata per nomen.

${ }^{14}$ This account of the two ways in which Aquinas uses ratio and its significance for Aquinas' theology of language is made by Klima, G. (2012) in 'Theory of Language' in B.Davies and E. Stumps (eds), The Oxford Handbook of Aquinas, Oxford: Oxford University Press. DOI: https://doi.org/10.1093/oxfordhb/9780195326093. $\underline{003.0028}$

${ }^{15}$ Est nihilominus communicable hoc nomen Deus, non secundum suam totam significationem, sed secundum aliquid eius, per quondam similitudinem, ut dii dicantur, qui participant aliquid divinum per similitudinem, secundum illud, ego dixi, dii estis.

16 Donum autem gratiae excedit omnem facultatem naturae creaturae, cum nihil aliud sit quam quaedam participatio divinae naturae, quae excedit omnem aliam naturam.

Sic enim necesse quod solus Deus deificet, communicando consortium divinae naturae per quandam similitudinis participationem.

17 There is an extended treatment of how Christian theology can use non-Christian thought in Aquinas' commentary on Boethius' De Trinitate, Aquinas Super de Trinitate 1.2.3. 